\title{
PENGETAHUAN TENTANG INFEKSI MENULAR SEKSUAL DENGAN PERILAKU SEKSUAL TIDAK AMAN PADA REMAJA PUTRI MALUKU TENGGARA BARAT DI DAERAH ISTIMEWA YOGYAKARTA
}

Firmina Th. Kora' ${ }^{1}$, Djaswadi Dasuki ${ }^{2}$, Djauhar Ismail ${ }^{3}$.

\begin{abstract}
Background: Based on the Indonesian Demographic and Health Survey (IDHS, 2012), adolescents' knowledge (females aged 15-24 years) about STI (Sexually Transmitted Disease) is still low under 50\%. A total of $16.46 \%$ Indonesian adolescents have had sex, $46.26 \%$ of them have been doing it actively, first sex occurred in below 20 years of age.

Objective: To determine the relationship between knowledge about sexually transmitted infections with unsafe sexual behavior.

Method: This study is a quantitative and qualitative with cross-sectional study design. Subjects in this study were all female adolescents of West Southeast Moluccas who are continuing education in Yogyakarta. Univariable and bivariable data analysis was conducted using chi-square test statistic. Multivariable analysis was conducted using logistic regression to estimate the effective model.

Result and Discussion: Low knowledge STI is practically and statistically related to unsafe sexual behavior with a $p$-value $<0.05, R P 1.71$ and $C l 1.07$ to 2.70 . Low knowledge about STIs in adolescents increase the risk by 1.7 times for unsafe sexual behavior.

Conclusion: $67,1 \%$ female adolescent who have unsafe sexual behavior. Female adolescents who have knowledge about STIs low 65.7\%. Low knowledge STI significantly increases unsafe sexual behavior in adolescent girls. Unsafe sexual behavior conducted by adolescent female are sexual intercourse before the age of 20 not using condoms during sexual intercourse, and multiple sexual partner.
\end{abstract}

Keywords: Knowledge of Sexually Transmitted Infections, Unsafe Sexual Behavior, Female Adolescent.

\begin{abstract}
ABSTRAK
Latar Belakang: Berdasarkan data SDKI (Survei Demokrasi Kesehatan Indonesia) 2012, pengetahuan remaja (wanita umur 15-24 tahun) tentang IMS (Infeksi Menular Seksual) masih rendah dibawah 50\%. Remaja indonesia telah melakukan hubungan seks sebanyak 16,46\%, 46,26\% diantara mereka telah melakukannya secara aktif, seks pertama terjadi pada umur dibawah 20 tahun.

Tujuan: Untuk mengetahui hubungan antara pengetahuan tentang infeksi menular seksual dengan perilaku seksual tidak aman.

Metode: Penelitian ini adalah penelitian kuantitatif dan kualitatif dengan rancangan cross sectional study. Subjek dalam penelitian ini adalah semua remaja putri Maluku Tenggara Barat yang sedang melanjutkan pendidikan di Daerah Istimewa Yogyakarta. Analisis data dilakukan secara univariabel, bivariabel dengan

1 Kesehatan Ibu dan Anak-Kesehatan Reproduksi, Program Pasca Sarjana,

Fakultas Kedokteran, Universitas Gadjah Mada.

2 Bagian Obstetri dan Ginekologi, Fakultas Kedokteran, Universitas Gadjah Mada.

3 Poliklinik Tumbuh Kembang Anak, Rumah Sakit Umum Pemerintah Dr. Sardjito, Yogyakarta
\end{abstract}


uji statistik chi-square. Analisis multivariabel menggunakan regresi logistik untuk memperkirakan model yang efektif.

Hasil dan Pembahasan: Pengetahuan tentang IMS berhubungan dengan perilaku seksual tidak aman pada remaja. Pengetahuan tentang IMS yang rendah berhubungan secara praktis dan statistik terhadap perilaku seksual tidak aman dengan nilai $\mathrm{p}$-value $<0,05$ dan $R P$ 1,71 dan $C l$ 1,07-2,70. Pengetahuan tentang IMS yang rendah pada remaja dapat berisiko sebesar 1,7 kali untuk berperilaku seksual tidak aman.

Kesimpulan: Remaja putri yang melakukan perilaku seksual tidak aman sebanyak $67,1 \%$. Sebanyak $65,7 \%$ remaja putrid memiliki pengetahuan yang rendah tentang IMS. Pengetahuan tentang IMS yang rendah bermakna meningkatkan perilaku seksual tidak aman pada remaja putri. Perilaku seksual tidak aman yang dilakukan oleh remaja putri yaitu melakukan hubungan seksual sebelum umur 20 tahun, tidak menggunakan kondom pada saat behubungan seks, dan berganti pasangan seksual lebih dari satu.

Kata Kunci: Pengetahuan Infeksi Menular Seksual, Perilaku Seksual Tidak Aman, Remaja Putri.

\section{PENDAHULUAN}

Infeksi Menular Seksual (IMS) adalah penyakit infeksi yang penularannya terutama melalui hubungan seksual. Infeksi Menular Seksual (IMS) sampai saat ini masih merupakan masalah kesehatan masyarakat di seluruh dunia, baik di negara maju (industri) maupun di negara berkembang. World Health Organization memperkirakan terdapat lebih dari 340 juta kasus baru dari IMS yang dapat diobati seperti sifilis, gonorrhea, klamidia trakomatis dan trikomonas vaginalis yang terjadi setiap tahun di dunia, terutama pada pria dan wanita berusia 15- 49 tahun. ${ }^{13}$ Berdasarkan data dari CDC pada tahun 2012 lebih dari 2,8 juta kasus Chlamydia dan lebih dari 700.000 kasus gonorrhea yang terjadi pada remaja di Amerika Serikat. ${ }^{7}$

Berdasarkan Survei Demografi dan Kesehatan Indonesia (SDKI, 2012), pengetahuan remaja (pria dan wanita umur 15-24 tahun) tentang IMS masih rendah dimana 35\% wanita dan 19\% pria mengetahui gonorrhea, 14\% wanita dan $4 \%$ pria mengetahui genital herpes, sedangkan pengetahuan mengenai condylomata, chancroid, chlamydia, candida, dan jenis IMS lain tergolong sangat rendah (dibawah 1\%). Berdasarkan hasil Survei Kesehatan Reproduksi Remaja Indonesia
(SKRRI), 7 dari 10 pria dan wanita (masing-masing 72\%) tidak memiliki pengetahuan tentang gejala IMS. Pengetahuan tentang gejala IMS lebih rendah pada wanita dan pria yang lebih muda.

Hubungan seks pertama kali yang terlalu muda akan meningkatkan risiko terinfeksi IMS. Perilaku remaja yang rentan terhadap IMS meliputi: terlalu dini melakukan hubungan seks, tidak konsisten memakai kondom, melakukan aktifitas seks tanpa perlindungan, berhubungan seks dengan pasangan yang beresiko atau berganti-ganti pasangan. ${ }^{12}$ Hasil survei SDKI 2012 Kesehatan Reproduksi Remaja) KRR menunjukkan bahwa sekitar 9,3\% atau sekitar 3,7 juta remaja menyatakan pernah melakukan hubungan seksual pranikah, sedangkan hasil SKRRI 2007 hanya sekitar 7\% atau sekitar 3 juta remaja. Data ini menunjukkan bahwa selama periode tahun 2007 sampai 2012 terjadi peningkatan kasus remaja yang pernah melakukan hubungan seksual sebanyak $2,3 \%$.

Berdasarkan observasi yang dilakukan pada beberapa remaja MTB (Maluku Tenggara Barat) diketahui bahwa 2 dari 5 remaja tidak mengetahui tentang infeksi menular seksual, ada juga yang mempunyai kebiasaan pergi ke klub malam, merokok, dan berganti-ganti pacar. 
Dampak pergaulan bebas mengantarkan pada kegiatan menyimpang seperti seks bebas, tindak kriminal termasuk aborsi, penyalahgunaan narkoba, serta berkembangnya infeksi menular seksual (IMS). Berdasarkan hal tersebut maka peneliti perlu melakukan sebuah penelitian untuk melihat hubungan antara pengetahuan tentang IMS dengan perilaku seksual tidak aman pada remaja putri.

\section{METODE PENELITIAN}

Penelitian ini adalah penelitian non eksperimental dengan rancangan cross-sectional study karena subyek diamati hanya sesaat atau satu kali, dengan pendekatan kuantitatif dan kualitatif. ${ }^{4}$ Subjek dan populasi dalam penelitian ini adalah semua remaja putri Maluku Tenggara Barat yang berdomisili di Daerah Istimewa Yogyakarta. Lokasi penelitian di Daerah Istimewa Yogyakarta. Cara pengambilan sampel untuk menjadi subjek penelitian dilakukan dua tahap, yaitu tahap pertama membagikan kuesioner kepada seluruh responden yang berjumlah 120 orang untuk mengetahui jumlah responden yang telah melakukan hubungan seksual. Tahap selanjutnya memisahkan data responden yang telah melakukan hubungan seksual dengan yang belum pernah melakukan hubungan seksual. Kemudian responden yang telah melakukan hubungan seksual sebanyak 70 orang di follow up untuk pengisian kuesioner selanjutnya. Data kualitatif responden didapatkan dengan cara wawancara mendalam pada empat responden.

Instrumen yang digunakan dalam penelitian ini adalah kuesioner (Pertanyaan tentang tingkat pendidikan; Kuesioner berisi pertanyaan pengetahuan remaja tentang infeksi menular seksual) yang dimodifikasi dari kuesioner SDKI 2012 dan penelitian yang dilakukan oleh Stoskopf (1999). Hasil ukur untuk variabel ini adalah tinggi jika nilai kuesioner yang diperoleh $>13$, sedangkan rendah jika nilai kuesioner < 13; Kuesioner pertanyaan tentang perilaku seksual remaja yang dimodifikasi dari kuesioner SDKI 2012. Apabila remaja melakukan salah satu atau lebih perilaku (Melakukan hubungan seksual pertama pada usia < 20 tahun, berganti-ganti pasangan seks atau berhubungan seks dengan pasangan yang berisiko (orang baru dikenal), tidak memakai kondom pada saat berhubungan seks) maka remaja tersebut dikelompokan dalam perilaku seksual tidak aman dengan lambang penilaian = 1. Sebaliknya jika remaja tidak melakukan semua perilaku tersebut dikelompokkan dalam perilaku seksual yang aman dengan lambang penilaian $=0$; Kuesioner pertanyaan tentang Pengaruh Teman sebaya. Hasil ukur untuk variabel ini adalah berpengaruh buruk jika skor $>10$ dan pengaruh baik jika skor < 10; Kuesioner tentang pengaruh media masa, hasil ukur untuk variabel ini adalah $1=$ jika responden terpapar dua atau lebih informasi tentang infeksi menular seksual dan perilaku seksual. $0=$ jika responden terpapar satu informasi atau tidak mendapatkan informasi tentang infeksi menular seksual dan perilaku seksual.

Data kuantitatif dianalisis dengan cara sebagai berikut; 1) Analisis Univariat; Analisis ini dilakukan untuk menggambarkan karakteristik masing-masing variabel yang diteliti dengan menggunakan distribusi frekuensi, selanjutnya data ditampilkan dalam bentuk tabel dan narasi; 2) Analisis bivariat: analisis ini dilakukan untuk melihat hubungan variabel bebas dengan variabel terikat dengan menggunakan uji Chi-square pada tingkat kemaknaan $p<0.05$ dan Cl 95\% (sedangkan nilai $R P$ dihitung dengan uji statistic Chi-square test); 3) Analisis multivariat: dilakukan untuk mengetahui hubungan antara variabel bebas dan variabel terikat dengan mengontrol variabel lain. Uji yang digunakan yaitu regresi logistik (logistic regression) dengan tingkat kemaknaan $p<0.05$, nilai $\mathrm{R}^{2}$, dan nilai deviance.

Data kualitatif dilakukan untuk memperkuat data kuantitatif dengan menganalisis hasil dari wawancara mendalam. Langkah-langkah yang 
dilakukan sebagai berikut: 1) mendengarkan ulang hasil rekaman sambil membuat transkrip wawancara; 2) mengelompokkan data; 3) menyajikan data dalam bentuk deskriptif, analisis konten dan mengambil kesimpulan.

\section{HASIL DAN PEMBAHASAN}

Subjek dalam penelitian ini berjumlah 70 orang. Analisis kuantitatif yang digunakan adalah univariabel, bivariabel, dan multivariabel.

Analisis univariabel menunjukkan bahwa lebih dari setengah subjek yang disurvei (67.1\%) melakukan perilaku seksual yang tidak aman dan memiliki pengetahuan tentang IMS yang rendah (65.7\%). Sebagian besar subjek berpendidikan rendah (75.7\%). Lebih dari $60 \%$ subjek mendapatkan pengaruh yang buruk dari teman sebaya dan lebih dari $50 \%$ subjek terpapar oleh media massa.

\section{Analisis Bivariabel}

Analisis ini bertujuan untuk mengetahui hubungan antara pengetahuan tentang IMS
Tabel 1. Distribusi variabel penelitian

\begin{tabular}{lcc}
\hline Variabel & $\mathrm{n}$ & $\%$ \\
\hline Perilaku seksual tidak aman & & \\
Tidak aman & 47 & 67.1 \\
Aman & 23 & 32.9 \\
Pengetahuan tentang IMS & & \\
Rendah & 46 & 65.7 \\
Tinggi & 24 & 34.3 \\
Tingkat Pendidikan & & \\
Rendah & 53 & 75.7 \\
Tinggi & 17 & 24.3 \\
Pengaruh teman sebaya & & \\
Buruk & 43 & 61.4 \\
Baik & 27 & 38.6 \\
Pengaruh media masa & & \\
Terpapar & 36 & 51.4 \\
Tidak terpapar & 34 & 48.6 \\
\hline
\end{tabular}

Sumber: Data Primer

terhadap perilaku seksual tidak aman pada remaja dengan melihat nilai dari Ratio prevalence (Rp), $p$-value ( $p$ ) dan Confidence interval (CI).

Tabel 2. Hubungan pengetahuan tentang IMS dengan perilaku seksual tidak aman

\begin{tabular}{|c|c|c|c|c|c|c|c|c|}
\hline & \multicolumn{4}{|c|}{ Perilaku seksual } & \multirow{3}{*}{$\chi^{2}$} & \multirow{3}{*}{$\mathrm{p}$} & \multirow{3}{*}{$\mathrm{RP}$} & \multirow{3}{*}{$95 \% \mathrm{Cl}$} \\
\hline & \multicolumn{2}{|c|}{ Tidak aman } & \multicolumn{2}{|c|}{ Aman } & & & & \\
\hline & $\mathrm{n}$ & $\%$ & $\mathrm{n}$ & $\%$ & & & & \\
\hline \multicolumn{9}{|c|}{ Pengetahuan tentang IMS } \\
\hline Rendah & 36 & 78.3 & 10 & 21.7 & 7.51 & 0.006 & 1.71 & $1.07-2.70$ \\
\hline Tinggi & 11 & 45.8 & 13 & 54.2 & & & 1 & \\
\hline
\end{tabular}

Berdasarkan tabel 2 di atas didapatkan data bahwa pengetahuan tentang IMS yang rendah berhubungan secara praktis dan statistik terhadap perilaku seksual tidak aman dengan nilai $p<0,05$ dan RP 1,71. Hal ini menunjukkan bahwa remaja yang memiliki pengetahuan tentang IMS yang rendah memiliki risiko sebesar lebih dari satu setengah kali untuk melakukan perilaku seksual tidak aman dibandingkan dengan remaja yang berpengetahuan tinggi. 
Tabel 3. Hubungan tingkat pendidikan, pengaruh teman sebaya dan pengaruh media masa dengan perilaku seksual tidak aman.

\begin{tabular}{|c|c|c|c|c|c|c|c|c|}
\hline & \multicolumn{4}{|c|}{ Perilaku seksual } & \multirow{3}{*}{$\chi^{2}$} & \multirow{3}{*}{$p$} & \multirow{3}{*}{$\mathrm{RP}$} & \multirow{3}{*}{$95 \% \mathrm{Cl}$} \\
\hline & \multicolumn{2}{|c|}{ Tidak aman } & \multicolumn{2}{|c|}{ Aman } & & & & \\
\hline & $\mathrm{n}$ & $\%$ & $\mathrm{~N}$ & $\%$ & & & & \\
\hline \multicolumn{9}{|c|}{ Tingkat Pendidikan } \\
\hline Rendah & 37 & 69.8 & 16 & 30.2 & 0.70 & 0.401 & 1.19 & $0.76-1.83$ \\
\hline Tinggi & 10 & 58.8 & 7 & 41.2 & & & 1 & \\
\hline \multicolumn{9}{|c|}{ Pengaruh teman sebaya } \\
\hline Buruk & 34 & 79.1 & 9 & 20.9 & 7.18 & 0.007 & 1.64 & $1.07-2.50$ \\
\hline Baik & 13 & 48.2 & 14 & 51.8 & & & 1 & \\
\hline \multicolumn{9}{|c|}{ Pengaruh media masa } \\
\hline Terpapar & 30 & 83.3 & 6 & 16.7 & 8.80 & 0.003 & 1.66 & $1.15-2.40$ \\
\hline Tidak terpapar & 17 & 50.0 & 17 & 50.0 & & & 1 & \\
\hline
\end{tabular}

Tabel 3 menunjukkan bahwa secara praktis tingkat pendidikan berhubungan terhadap perilaku seksual tidak aman, tetapi secara statistik tidak menunjukkan hubungan yang signifikan dengan nilai $\mathrm{p}>0,05, \mathrm{RP} 1,19$, dan $95 \% \mathrm{Cl}(0,76$ 1,83). Artinya remaja yang memiliki tingkat pendidikan menengah berisiko hampir satu koma dua kali untuk melakukan perilaku seksual tidak aman dibandingkan yang berpendidikan tinggi.

Pengaruh teman sebaya berhubungan bermakna secara praktis dan statistik dengan perilaku seksual tidak aman. Hal ini terlihat dari nilai $p<0,05$, RP 1,64 dan 95\% $\mathrm{Cl}(1,07-2,5)$. Artinya remaja yang mendapatkan pengaruh yang buruk dari teman sebaya berisiko hampir satu koma tujuh kali untuk melakukan perilaku seksual tidak aman dibandingkan remaja yang mendapatkan pengaruh baik dari teman sebaya. Pengaruh media masa secara statistik dan praktis memiliki hubungan yang bermakna terhadap perilaku seksual tidak aman dengan nilai $p<0,05$, $\mathrm{RP} 1,66$ dan $95 \% \mathrm{Cl}(1,15-2,40)$. Artinya remaja yang terpapar media masa berisiko hampir satu koma tujuh kali untuk melakukan perilaku seksual tidak aman.

Analisis bivariabel dilakukan untuk melihat perbedaan antara variabel pengetahuan tentang IMS sebagai variabel bebas dengan variabel luar. Hasilnya menunjukkan bahwa variabel bebas dengan variabel luar tidak menunjukkan hubungan yang signifikan. Hasil ini didapatkan karena nilai $p>0,05$ pada tingkat kepercayaan 95\% dan nilai $\mathrm{Cl}$ yang melewati angka nol. 
Tabel 4. Hubungan variabel tingkat pendidikan, pengaruh teman sebaya dan pengaruh media masa dengan pengetahuan tentang IMS.

\begin{tabular}{|c|c|c|c|c|c|c|c|c|}
\hline & \multicolumn{4}{|c|}{ Pengetahuan tentang IMS } & \multirow{3}{*}{$\chi^{2}$} & \multirow{3}{*}{$\mathrm{p}$} & \multirow{3}{*}{$\mathrm{RP}$} & \multirow{3}{*}{$95 \% \mathrm{Cl}$} \\
\hline & \multicolumn{2}{|c|}{ Rendah } & \multicolumn{2}{|c|}{ Tinggi } & & & & \\
\hline & $\mathrm{n}$ & $\%$ & $\mathrm{n}$ & $\%$ & & & & \\
\hline \multicolumn{9}{|c|}{ Tingkat Pendidikan } \\
\hline Rendah & 34 & 64.2 & 19 & 35.8 & 0.23 & 0.62 & 0.91 & $0.62-1.31$ \\
\hline Tinggi & 12 & 70.6 & 5 & 29.4 & & & 1 & \\
\hline \multicolumn{9}{|c|}{ Pengaruh teman sebaya } \\
\hline Buruk & 29 & 67.4 & 14 & 32.6 & 0.14 & 0.70 & 1.07 & $0.75-1.52$ \\
\hline Baik & 17 & 63.0 & 10 & 37.0 & & & 1 & \\
\hline \multicolumn{9}{|c|}{ Pengaruh media masa } \\
\hline Terpapar & 26 & 72.2 & 10 & 27.8 & 1.39 & 0.24 & 1.22 & $0.86-1.73$ \\
\hline Tidak terpapar & 20 & 58.8 & 14 & 41.2 & & & 1 & \\
\hline
\end{tabular}

\section{Analisis Multivariabel}

Analisis ini bertujuan untuk mengetahui pengaruh dari pengetahun tentang IMS terhadap perilaku seksual tidak aman dengan mempertimbangkan variabel tingkat pendidikan, pengaruh teman sebaya, dan pengaruh media masa. Berdasarkan hasil analisis bivariabel, variabel luar secara statistik yang bermakna akan dianalisis di dalam analisis regresi logistik dengan melihat nilai OR dan nilai Deviance.

Tabel 5. Analisis Regresi Logistik hubungan pengetahuan tentang IMS, pengatuh teman sebaya, dan pengaruh media massa dengan perilaku seksual tidak aman.

\begin{tabular}{|c|c|c|c|c|}
\hline & Model 1 & Model 2 & Model 3 & Model 4 \\
\hline & OR & OR & OR & OR \\
\hline & $\mathrm{Cl} 95 \%$ & $\mathrm{Cl} 95 \%$ & $\mathrm{Cl} 95 \%$ & $\mathrm{Cl} 95 \%$ \\
\hline \multicolumn{5}{|c|}{ Pengetahuan tentang IMS } \\
\hline \multirow[t]{2}{*}{ Rendah } & $4.25^{*}$ & $4.77^{*}$ & $4.04^{*}$ & $4.92 *$ \\
\hline & $(1.46-12.34)$ & $(1.50-15.14)$ & $(1.29-12.64)$ & $(1.46-16.53)$ \\
\hline Tinggi & 1 & 1 & 1 & 1 \\
\hline \multicolumn{5}{|c|}{ Pengaruh teman sebaya } \\
\hline \multirow[t]{2}{*}{ Buruk } & & $4.56^{*}$ & & $3.58^{*}$ \\
\hline & & $(1.45-14.29)$ & & $(1.07-11.89)$ \\
\hline Baik & & 1 & & 1 \\
\hline \multicolumn{5}{|c|}{ Pengaruh media masa } \\
\hline \multirow[t]{2}{*}{ Terpapar } & & & $4.78^{*}$ & $3.93 *$ \\
\hline & & & $(1.50-15.24)$ & $(1.13-13.57)$ \\
\hline Tidak terpapar & & & 1 & 1 \\
\hline $\mathrm{R}^{2}$ & 0.08 & 0.16 & 0.17 & 0.22 \\
\hline Deviance & 81.27 & 73.98 & 73.54 & 68.97 \\
\hline $\mathrm{N}$ & 70 & 70 & 70 & 70 \\
\hline
\end{tabular}

$*^{*}=p$ value $<0.05$ 
Model 1 dibuat untuk melihat hubungan pengetahuan tentang IMS terhadap perilaku seksual tidak aman sebelum mempertimbangkan variabel luar. Pada model 1 variabel pengetahuan signifikan terhadap perilaku seksual tidak aman dengan nilai OR sebesar 4.25. Model 1 memberikan kontribusi sebesar $8 \%$ terhadap perilaku seksual tidak aman.

Model 2 dibuat untuk melihat hubung-an pengetahuan tentang IMS dengan mempertimbangkan pengaruh teman sebaya. Pengaruh teman sebaya memberikan risiko sebesar empat setengah kali terhadap perilaku seksual tidak aman. Model 2 dapat memprediksi perilaku seksual tidak aman sebesar $16 \%$ ketika remaja memiliki pengetahuan yang rendah tentang IMS dan mendapatkan pengaruh yang buruk dari teman sebaya.

Model 3 dibuat untuk melihat hubung-an pengetahuan tentang IMS dengan mempertimbangkan pengaruh media masa terhadap perilaku seksual tidak aman. Remaja yang terpapar media massa berisiko untuk melakukan perilaku seksual tidak aman sebesar hampir 4,8 kali dibandingkan remaja yang tidak terpapar media masa. Media massa dapat memprediksi remaja dalam berperilaku seksual tidak aman sebesar $17 \%$ ketika remaja memiliki pengetahuan yang rendah tentang IMS.

Model 4 dibuat untuk melihat hubung-an pengetahuan tentang IMS dengan mempertimbangkan pengaruh teman sebaya dan pengaruh media massa terhadap perilaku seksual tidak aman. Setelah dikontrol oleh variabel Pengaruh teman sebaya dan pengaruh media massa, maka model ini dapat memprediksi remaja dalam berperilaku seksual tidak aman meningkat dari $8 \%$ menjadi $22 \%$.

Dengan pemodelan yang dipaparkan pada tabel 4 dan membandingkan hasil analisis pada model-model yang sudah dibuat dipilih salah satu model yang cukup efektif yaitu model 4 . Model 4 lebih efektif dibandingkan model lain karena semua variabel mempunyai hubungan yang signifikan, nilai $\mathrm{R}^{2}$ lebih tinggi dibandingkan model lain yaitu 0,22 , serta nilai deviance yang lebih kecil dengan beberapa model lain yaitu 68,97 .

Dari hasil analisis kualitatif dapat dijelaskan bahwa remaja mulai mengenal perilaku seksual semenjak pacaran. Sebagian remaja mulai berpacaran pada jenjang SMA. Adapun remaja mulai tertarik dengan perilaku seksual karena ada rasa penasaran dan ingin tahu tentang seks, pengaruh teman sebaya serta pengaruh dari media. Remaja mulai berperilaku seksual ketika telah mempunyai pasangan (pacar). Ada remaja yang merasa terganggu aktifitas kuliahnya karena sering ketemu, ada juga yang merasa tidak terganggu kuliahnya. Hal yang menjadi faktor risiko remaja untuk berperilaku seksual diantaranya faktor individu remaja sendiri yang sedang dalam masa pubertas, yang mengakibatkan muncul dorongan hasrat untuk berperilaku seksual; kurang perhatian dari orang tua; dan terpengaruh informasi tentang seksual dari teman sebaya maupun media.

Aktifitas seksual yang sering dilakukan remaja pada saat pacaran adalah berpelukan, berciuman, oral seksual, bahkan sampai melakukan hubungan seksual. Hubungan seksual merupakan perilaku seksual remaja yang paling berisiko, karena jika remaja berani melakukan hal tersebut, berarti remaja harus siap untuk menerima segala risiko yang dihadapi, misalnya dapat tertular Infeksi Menular Seksual, HIV/AIDS, dan lain-lain. Kisaran usia pertama melakukan hubungan seksual adalah 18-20 tahun.

Perilaku seksual tidak amann pada remaja diantaranya melakukan hubungan seksual dibawah 20 tahun, melakukan oral seksual, melakukan hubungan seksual tanpa kondom, 
dan sering berganti pasangan seksual. Hal ini disebabkan remaja tidak tahu tentang seksual yang aman. Sebagian besar remaja juga tidak mengetahui tentang infeksi menular seksual. Hal ini sesuai dengan penelitian yang mengatakan perilaku remaja yang rentan terhadap IMS meliputi: terlalu dini melakukan hubungan seksual, tidak konsisten memakai kondom, melakukan aktifitas seksual tanpa perlindungan, berhubungan seksual dengan pasangan yang beresiko atau berganti-ganti pasangan. ${ }^{12}$

Jumlah subyek penelitian sebanyak 70 responden. Berdasarkan hasil penelitian sebanyak $67,1 \%$ responden berperilaku seksual tidak aman, sedangkan yang berperilaku seksual aman sebanyak 32,9\%. Hal ini sejalan dengan penelitian di Ethipohia utara yang menemukan sebanyak $49,7 \%$ remaja telah melakukan hubungan seksual pranikah pada umur sebelum 20 tahun. $^{8}$ Sekitar 62\% remaja melaporkan bahwa mereka tidak menggunakan kondom pada aktivitas seksual terakhir mereka. Berdasarkan hasil wawancara mendalam, responden menggungkapkan alasan tidak menggunakan kondom karena dapat mengurangi kenikmatan. Hal ini sesuai dengan penelitian yang mengatakan adanya persepsi bahwa penggunaan kondom mengurangi kenikmatan seksual, pasangan tidak mau menggunakan kondom, serta kurangnya diskusi mengenai kondom dimungkinkan menjadi penyebab mengapa remaja sangat minim dalam penggunaan kondom selama mereka melakukan hubungan seksual. ${ }^{1}$

Dari hasil analisis bivariabel dan multivariabel, menunjukkan hubungan yang signifikan antara pengetahuan tentang IMS dengan perilaku seksual tidak aman. Dari hasil perhitungan statistik diketahui $R P 1,71, p$-value 0.006, dan $\mathrm{Cl}$ 1.07-2.70. Pengetahuan tentang IMS yang rendah pada remaja dapat berisiko sebesar 1,7 kali untuk berperilaku seksual tidak aman. Hal ini sesuai dengan penelitian yang menyatakan bahwa remaja yang tertular IMS memiliki pengetahuan yang rendah tentang IMS. ${ }^{2}$ Berdasarkan hasil penelitian ini, diketahui bahwa remaja putri dengan pengetahuan IMS yang rendah adalah sebesar $65,7 \%$. Hal ini sesuai dengan penelitian yang menemukan bahwa $53 \%$ responden mempunyai pengetahuan yang rendah tentang infeksi menular seksual. ${ }^{11}$ Rendahnya pengetahuan tentang IMS merupakan penyebab dari perilaku berisiko untuk tertular IMS dan penyebaran HIV/AIDS. ${ }^{9}$ Hasil penelitian ini juga membuktikan bahwa responden dengan tingkat pengetahuan rendah tentang IMS berpeluang hampir 2 kali untuk melakukan perilaku seksual tidak aman dibandingkan responden dengan tingkat pengetahuan tinggi. Hal ini sesuai dengan hipotesis penelitian.

Hasil penelitian pada remaja dengan tingkat pendidikan rendah memberikan informasi Ratio Prevalance sebesar 1.19, p-value 0.401, dan Cl 0.76-1.83 meskipun tidak bermakna secara statistik dengan perilaku seks tidak aman, tetapi dapat diinformasikan bahwa remaja dengan tingkat pendidikan rendah mempunyai peluang sebesar 1,2 kali untuk berperilaku seksual yang tidak aman.

Variabel pengaruh teman sebaya dinyatakan bermakna dengan perilaku seksual tidak aman. Variabel pengaruh teman sebaya memiliki peluang sebesar 1,64 kali pada remaja untuk berperilaku seksual tidak aman. Hasil analisis kulitatif juga mendukung hasil penelitian kuantitatif. Responden yang memiliki perilaku seksual tidak aman ternyata mendapatkan pengaruh buruk dari teman sebaya. Hubungan dengan teman sebaya sangat berpengaruh dengan perilaku seksual remaja. Apabila seorang remaja memiliki teman yang aktif secara seksual maka akan semakin besar kemungkinan remaja tersebut untuk juga aktif secara seksual mengingat bahwa pada usia tersebut remaja ingin diterima oleh lingkungannya. ${ }^{6,10}$ 
Pada variabel pengaruh media massa, keterpaparan remaja terhadap media massa menunjukkan hubungan yang bermakna dengan perilaku seksual tidak aman. Remaja dalam masa perkembangannya sangat intens mencari informasi mengenai norma seksual untuk mendukung perannya untuk menjadi dewasa. Namun informasi tersebut kurang tersedia bagi remaja sehingga remaja mencari informasi tentang norma seksual melalui media. Di antara teman, pendidikan kesehatan, maka media merupakan sumber informasi yang utama bagi remaja. ${ }^{5} \mathrm{Hal}$ ini sesuai dengan hasil wawancara mendalam dimana remaja mencari informasi perilaku seksual melalui media massa (internet, film).

Hasil penelitian sebelumnya menunjukkan bahwa remaja yang lebih banyak terekspos isi media massa dilaporkan memiliki kecenderungan untuk lebih aktif melakukan hubungan seksual. Tayangan media massa sangat penting dalam perubahan perilaku seksual remaja. Semakin besar paparan informasi seksual remaja yang diperoleh, semakin besar dorongan remaja untuk melakukan aktivitas seksual. ${ }^{3}$

\section{KESIMPULAN DAN SARAN}

Berdasarkan hasil dan pembahasan maka dapat ditarik kesimpulan sebagai berikut: 1) Remaja putri MTB (Maluku Tenggara Barat) yang melakukan perilaku seksual tidak aman sebanyak 67,1\%. Remaja putri MTB yang memiliki pengetahuan tentang IMS rendah sebanyak $65,7 \%$; 2) Pengetahuan tentang IMS yang rendah bermakna meningkatkan perilaku seksual tidak aman pada remaja putri; 3) Perilaku seksual tidak aman yang dilakukan oleh remaja putri MTB yaitu melakukan hubungan seksual sebelum umur 20 tahun, tidak menggunakan kondom pada saat behubungan seksual, dan berganti pasangan seksual lebih dari satu.
Saran-saran yang dapat disampaikan; 1) Upaya peningkatan pengetahuan remaja putri MTB tentang kesehatan reproduksi dan perilaku seksual dapat dilakukan dengan memberikan materi penyuluhan pada saat kegiatan keorganisasian yang diadakan oleh HIKMA MTB-DIY; 2) Penyampaian materi tentang IMS dapat dilakukan melalui buletin bulanan yang diterbitkan oleh HIKMA MTB-DIY; 3) Bagi peneliti selanjutnya, diharapkan memasukkan faktor budaya untuk melihat adakah pengaruh bagi perilaku seksual remaja.

\section{DAFTAR PUSTAKA}

1. Brown, L.K., DiClemente, R., Crosby, R., Fernandez, M. I., Pugatch, D., Cohn, S., Lescabo, C., Royal, S., Murphy, J.R. \& Silver, B. (2008) Condom use among high-risk adolescents: Anticipation of partner disapproval and less pleasure associated with not using condoms. Public Health Reports, 123(5):601.

2. Carmine, L., Castillo, M. \& Fisher, M. (2014) Testing and Treatment for Sexually Transmitted Infections in Adolescents-What's New? J Pediatr Adolesc Gynecol, 27(2): 50-60.

3. Escobar, Chaves, Tortolero, S, Markharm, Carbara (2005) Impact of the Media on Adolescent Sexual Attitudes and Behaviors. Pediatrics 2005;116;30326.

4. Gordish, L.(2004) Epidemiologi, Unites Stated: Elsavier Saunders.

5. L'Engle, L.K., Brown, D.J., Kenneavy, K. (2006) The Mass Media are An Important Context for Adolescents'Sexual Behavior. Journal of Adolescent Health.38(2006):186-192.

6. Miller, L. (2000) Religiousty and substance use and abuse among adolescents in the national comorbidity survey. J Am Acad Child Adolesc Psychiatry, 39(9): 1190-7.

7. Robert, A, Mckie, MD. (2012) Sexually Transmitted Diseases. Prymary Care Reports. The Pratical, PeerReviewed Journal for Primary Care and Family Physicians.

8. Salih, N.A., Metaferia H., Reda A.A., Biadgilign S. (2014) Premarital sexual activity among unmarried adolescents in northern Ethiopia: a cross-sectional 
study. Sexual \& Reproductive Healthcare, Volume 6. 9-13.

9. Sansores, C., Lopez-Avila, M., Gongora-Biachi, R., \& Conocimientos, (2000) Impacto de Tres Medios de Ensenanza en Relacion con el Sindrome de.

10. Sieving, R.E., Jennifer A, R., Robert, O., \& Blum, W. (2002) Adolescent sexual behavior and sexual health. Pediatrics in Review, 23(12). 407-15.

11. Stoskopf A.L. (1999). College Students Knowledge of Sexually Transmitted Diseases. University of Wisconsin-Stout
12. Taylor, M. \& Seehafer, R.L. (2000) Risky Sexual Behavior Adolescent Women, JSPN, 5:1.

13. World Health Organization (2009) Promoting adolescent sexual and reproductive health through schools in low income countries: an information brief [Online].Available:http://whqlibdoc.who. int/hq/2009/WHO_FCH_CAH_ADH_09.03_eng. pdf[Accessed 24 Maret 2014]. 